\title{
Biomass and Carbon Stocks of Different Tree Plantations in Entisol Soil of Eastern Chhattisgarh India
}

\author{
ATUL KUMAR BHARDWAJ and K K CHANDRA* \\ Department of Forestry, Wildlife and Environmental Sciences, \\ Guru Ghasidas Central University, Bilaspur - 495009 India. \\ *Corresponding author Email: kkckvk@gmail.com \\ http://dx.doi.org/10.12944/CWE.11.3.17
}

(Received: August 27, 2016; Accepted: November 20, 2016)

\begin{abstract}
In present study, biomass and carbon accumulated in different tree species plantations after 25 year age of planting in entisol soil was evaluated. Plant attributes viz MAI diameter, MAI height, $A G B$ and $B G B$ and total biomass of trees exhibited significant variations among tree species however, A. lebbeck was found to have highest MAI diameter while E. globulus scored the highest MAI height among all other trees of investigation. Total biomass was found maximum $30.16 \mathrm{q} /$ tree followed with $16.66 \mathrm{q} /$ tree in $A$. lebbeck and $E$. globulus respectively as compared to average biomass of all tree species (8.15 q/tree). The performances of $D$. indica and $D$. sissoo were poor as they rendered less biomass in entisol soil. Total carbon stocks of plantation was estimated highest $(942.50 \mathrm{t} / \mathrm{ha})$ in $A$. lebbeck followed by E. globulus (520.62 t/ha), T. arjuna (143.12 t/ha), A. indica (106.87 t/ha) etc.
\end{abstract}

Keywords: Mean Annual Increment, Biomass, Entisol soil, Carbon storage.

\section{INTRODUCTION}

Trees play a vital role in mitigating the diverse effects of environmental carbon degradation and on reducing global warming. Trees promote sequestration of carbon into soil and plant biomass. Therefore, tree based land use practices could be viable alternatives to store atmospheric carbon dioxide due to their cost effectiveness, high potential of carbon uptake and associated environmental as well as social benefits ${ }^{1}$. But due to large scale deforestation of natural vegetation has reached 5.2 million hectares in the past ten years ${ }^{2}$ has impaired the carbon sequestration capacity of the biosphere. Moreover the release of inactive carbon from consumption and burning of fossil fuels through power industries has led to a considerable increase of $C$ in the atmosphere ${ }^{3}$. To prevent global warming, it is legally imperative to lowered $\mathrm{C}$ either by reducing emissions or by enabling the storage of carbon in the terrestrial ecosystems.
As forests maintain over $86 \%$ of the terrestrial carbon stock on earth during photosynthesis and storing excess carbon as biomass, an accurate estimate of forest carbon storage including natural forests, plantations, grass lands etc. separately for different forests of various locality, will be of great significance to the research on the productivity of terrestrial ecosystem, carbon cycle and global warming. Generally predictions of the sequestration rate of different tree species cannot be made, since growth and sequestration depends on local climate, soil factors and management. The rate of carbon sequestration depends on the growth characteristics of the tree species, the conditions for growth where the tree is planted, and the density of the tree's wood ${ }^{4}$. Over last 20 years, plenty of researches focusing of the carbon storage, carbon density and carbon sink function of forest ecosystem have been made by many countries ${ }^{5}$.

Entisol soil occupies 18.76 percent in Chhattisgarh state and 5.15 percent in Bilaspur 
district is categorized as waste land because it only supports pastures due to nutrient deficiencies and adverse physical properties. After tedious efforts only few tree species survives in bhata land. In the present study, 25 year old forest plantations were selected to assess the magnitude of biomass and carbon storage by different species with objective to evaluate the potential tree species for bhata land (entisol) rejuvenation.

\section{MATERIALS AND METHODS}

Experiment site is located between $82.15^{\circ}$ E longitude and $22.09^{\circ} \mathrm{N}$ latitude in Bilaspur, district of Chhattisgarh at an altitude of about 264 meters above mean sea level. It is roughly $19 \mathrm{~km}$ South to the Bilaspur city and the soil of the site is red entisol with red oxide deposits and is nutrient deficient. The climate is pleasant and mild in the winter (minimum temperature $10{ }^{\circ} \mathrm{C}$ ). There are medium rains $(1320 \mathrm{~mm})$ in the monsoon season. The summers are very hot and dry, with maximum temperature $45^{\circ} \mathrm{C}$. The selected area is only $10 \mathrm{~km}$ away from industrial zone of the Bilaspur city, where steel, motor, chemical and fertilizer industries and power plants etc. are located.

In order to understand how carbon sequestration patterns vary among plantation types, the carbon stock in eight tropical plantations using non-destructive method. The present study was carried out in Chakrabhatha Plantation Block of Bilaspur district during the year 2015. The whole plantation extent in over 100 ha with Kala siris (Albizia lebbeck), Neem (Azadirachta indica), Shisham (Dalbergia sissoo), Nilgiri (Eucalyptus globulus), Aonla (Emblica officinalis), Arjun (Terminalia arjuna), Peltaphorum (Peltophorum ferruginium) and Karanj (Deris indica) species in $4 \times 4 \mathrm{~m}$ distance accommodating 625 plants per hectare. After survey of the entire area, trees were enumerated according to diameter at breast height $(1.37 \mathrm{~m})$ in $50 \times 50 \mathrm{~m}$ sample plots. Total 156 trees were considered for each species in order to determine diameter at breast height and height and divided with the age of plantation for the calculation of Mean Annual Increment diameter (MAID) and Mean Annual Increment height (MAIH) by using measuring tape and Abney's level.
Volume of the tree was measured by the formula

$\mathrm{V}=\pi \mathrm{r}^{2} \mathrm{~h}$

Where, $\mathrm{V}=$ volume of the tree in $\mathrm{m}^{3}$, $\mathrm{r}=$ radius of the trunk in $\mathrm{m}, \mathrm{h}=$ Height of the tree. As very less taper was observed in trees, hence average volume was estimated by using above formula.

AGB (Above ground biomass) includes the all living biomass above the soil. AGB are calculated by multiplying volume to the green wood density of the tree species.

$\mathrm{AGB}=\mathrm{V}^{*} \mathrm{D}$

Where, $A G B=$ Above Ground Biomass, $\mathrm{V}=$ Volume of the tree in $\mathrm{M}^{3}$ and $\mathrm{D}=$ Wood Density of species. Wood density is used from global wood density database ${ }^{6}$. The standard average density of $0.6 \mathrm{~g} / \mathrm{cm}^{3}$ is applied wherever the density value is not available for tree species.

BGB (Below Ground Biomass) has been calculated by the multiplying the AGB by 0.26 , as per factor prescribed by Hangarge et al. ${ }^{7}$.

$B G B=A G B^{\star} 0.26$

TB (Total Biomass) has calculated by the sum total of $A G B$ and $B G B$.

Total biomass $=\mathrm{AGB}+\mathrm{BGB}$

In present study, we have calculated carbon with assumption, that any tree species contain $50 \%$ of its biomass ${ }^{8}$.

Carbon storage $=$ Biomass $^{*} 50 \%$

The data were statistically analyzed by analysis of variance at P, 0.05 level using SPSS software.

\section{RESULT AND DISCUSSION}

MAI diameter and MAI height were significantly varied among tree plantations in entisol soil (Table 1). A. lebbeck and Eucalyptus globulus were the top most species with $1.724 \mathrm{~cm} /$ year and 
$1.197 \mathrm{~cm} /$ year mean annual diameter increment respectively. MAI diameter of other species ranged $0.570-0.787 \mathrm{~cm} /$ year. MAl height of $E$. globulus was highest $(0.86 \mathrm{~m} /$ year) followed by $A$. lebbeck $(0.82$ $\mathrm{m} /$ year), while the MAI height of other species were in between 0.536 to $0.600 \mathrm{~m} /$ year. Wood density was found maximum $0.94 \mathrm{~g} / \mathrm{cm}^{3}$ in $T$. arjuna followed by E. globulus $\left(0.87 \mathrm{~g} / \mathrm{cm}^{3}\right)$. The wood density recorded lowest in P. feruginum (0.6 g/ $\left.\mathrm{cm}^{3}\right)$ (Fig.1).

AGB of tree species in entisol soil is depicted in table-2, indicates that $A$. lebbeck and $E$. globulus species accumulated $17.71 \mathrm{q}$ and $7.01 \mathrm{q}$ higher AGB respectively as compared to the average biomass of all the species (6.22 q/tree) under studied. AGB shown by $D$. sissoo and $D$. indica were $1.37 \mathrm{q}$ and $2.16 \mathrm{q} /$ tree, which is lowest in the present investigation. Similarly BGB was also found highest in $A$. lebbeck ( $6.23 \mathrm{q} /$ tree) followed by $E$. globulus (3.43q/tree) as compared to average BGB of all species (1.68q/tree). TB of $A$. lebbeck estimated to be highest (30.16 q/tree) while the lowest biomass was observed in $D$. indica because of the poor growth in entisol soil. The fast growing tree species viz. $A$. lebbeck and E. globulus produced higher biomass than other species of present study. This was in confirmation of the results of Kaul et al. ${ }^{9}$, who have reported the higher annual biomass in Eucalyptus and Poplar due to its fast growth and rapid storage of carbon. Similarly, Pandya et al. ${ }^{10}$ also reported

Table1: MAI Diameter and MAI height of different tree plantations at 25 year age in entisol soil

\begin{tabular}{llcc}
\hline $\begin{array}{l}\text { S. } \\
\text { No. }\end{array}$ & Species & $\begin{array}{c}\text { MAl Diameter } \\
\mathbf{( c m})\end{array}$ & $\begin{array}{c}\text { MAl Height } \\
\mathbf{( M )}\end{array}$ \\
\hline 01 & Albizia lebbeck & 1.724 & 0.820 \\
02 & Azadiracta indica & 0.787 & 0.576 \\
03 & Dalbergia sissoo & 0.626 & 0.592 \\
04 & Emblica officinalis & 0.754 & 0.560 \\
05 & Eucalyptus globules & 1.197 & 0.864 \\
06 & Peltophorum ferruginum & 0.723 & 0.568 \\
07 & Deris indica & 0.570 & 0.536 \\
08 & Terminalia arjuna & 0.726 & 0.600 \\
& CD at p<0.05 & 0.051 & 0.032 \\
\hline
\end{tabular}

Table 2: Biomass accumulation and carbon storage of tree species plantations in entisol soil

\begin{tabular}{llccccc}
\hline $\begin{array}{l}\text { S. } \\
\text { No. }\end{array}$ & $\begin{array}{c}\text { AGB } \\
(\mathbf{Q} / \text { tree })\end{array}$ & $\begin{array}{c}\text { BGB } \\
(\mathbf{Q} / \text { tree })\end{array}$ & $\begin{array}{c}\text { Total } \\
\text { Biomass } \\
(\mathbf{Q} / \text { tree) }\end{array}$ & $\begin{array}{c}\text { Carbon } \\
\text { Stock } \\
(\mathbf{Q} / \text { tree) }\end{array}$ & $\begin{array}{c}\text { Yearly } \\
\text { Carbon } \\
\text { storage (t/ha) }\end{array}$ \\
\hline 1 & Albizia lebbeck & 23.93 & 6.23 & 30.16 & 15.08 & 37.70 \\
2 & Azadiracta indica & 2.71 & 0.71 & 3.42 & 1.71 & 4.275 \\
3 & Dalbergia sissoo & 2.16 & 0.57 & 2.73 & 1.36 & 3.375 \\
4 & Deris indica & 1.37 & 0.35 & 1.72 & 0.86 & 2.150 \\
5 & Emblica officinalis & 2.57 & 0.67 & 3.24 & 1.62 & 4.050 \\
6 & Eucalyptus globulus & 13.23 & 3.43 & 16.66 & 8.33 & 20.825 \\
7 & Peltophorum ferruginum & 2.18 & 0.57 & 2.75 & 1.37 & 3.425 \\
8 & Terminalia arjuna & 3.64 & 0.95 & 4.59 & 2.29 & 5.72 \\
& CD p <0.05 & 0.77 & 0.18 & 1.85 & 0.33 & 0.45 \\
\hline
\end{tabular}




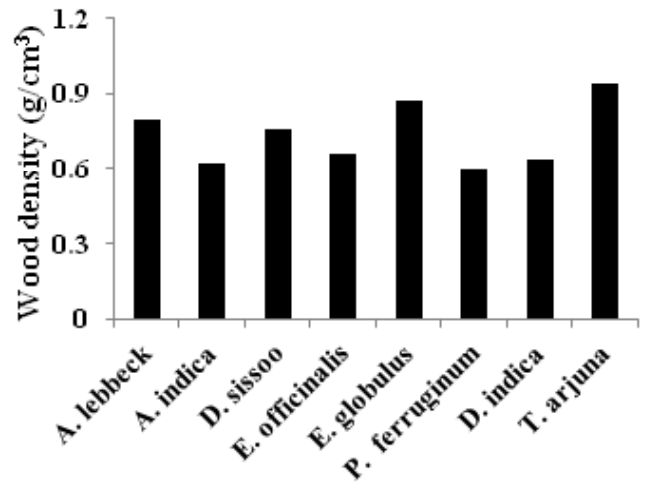

Fig. 1: Wood density of different tree species plantation

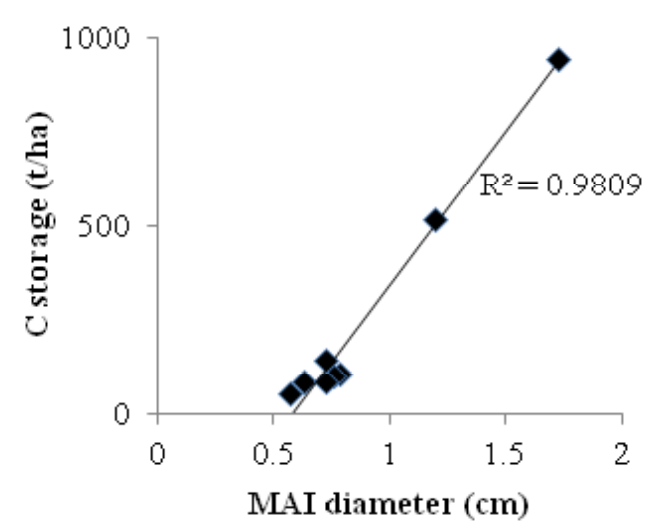

Fig. 2: Correlation between MAI Diameter X C storage

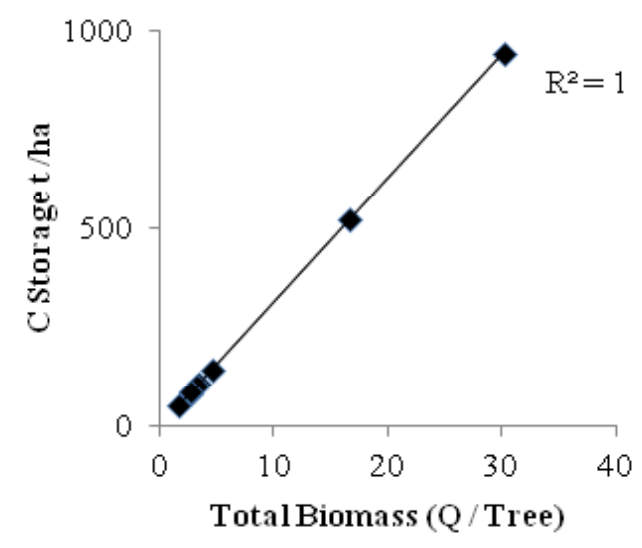

Fig. 4: Correlation between total biomass X C storage variations in carbon storage in different parts of tree species due to varied growth pattern.

Data on stored $\mathrm{C}$ in tree species in different plantations is depicted in table 2 revealed that $\mathrm{C}$ storage was strongly correlated with the diameter, height and biomass of the tree species and strongly positive $\mathrm{R}^{2}=0.98,0.796$ and 1 respectively (Fig. 2, 3 and 4). Higher the biomass, $C$ storage would be more in wood. As in present study, biomass of tree varied greatly in entisol soil and only two species namely $A$. lebbeck and $E$. globulus exhibited good yearly growth and thereby higher biomass than other species, results highest $\mathrm{C}$ storage $15.08 \mathrm{q} /$ tree and $8.33 \mathrm{q} /$ tree respectively, due to higher yearly C storage. The same attribute was calculated 1.37

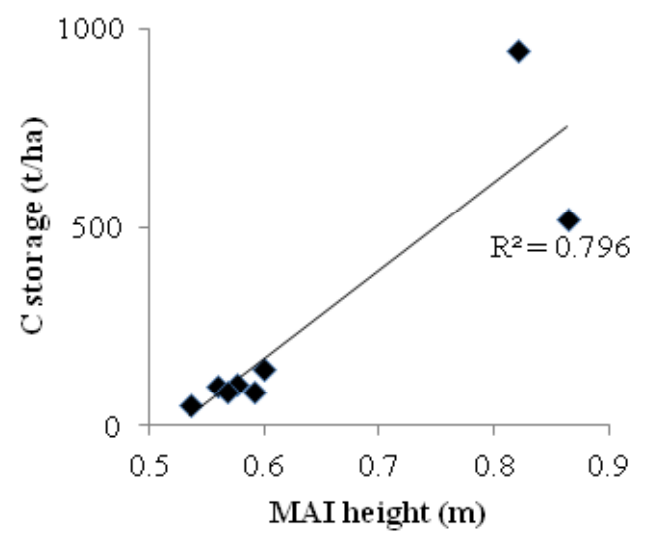

Fig. 3: Correlation between MAI height X C storage

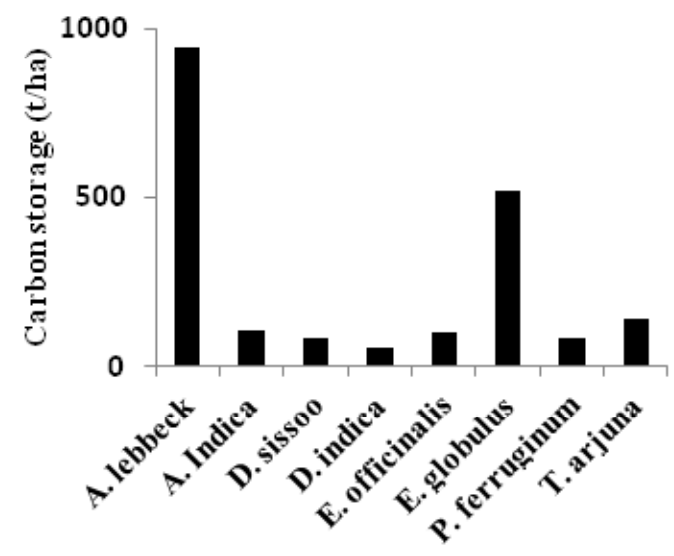

Fig. 5: Estimated C stocks in tree plantations in 25 years 
$\mathrm{q} /$ tree in $P$. ferruginum, $1.71 \mathrm{q} /$ tree in $A$. indica and $2.29 \mathrm{q} /$ tree in $T$. arjuna and minimum of $0.86 \mathrm{q} /$ tree in $D$. indica. This results concord with the findings of the other workers ${ }^{4,11,12}$. Estimated $C$ storage in one hectare plantation (Fig. 5) reveals that more than 942 t $\mathrm{C}$ could be stored through planting of $A$. lebbeck in one hectare area and 520.62 t C/ha by E. globulus at the age of 25 year in entisol soil. A. indica, $E$. officinalis and $T$. arjuna found to have potential to fix $C$ in range between $101-143$ t/ha when selected for field plantations in wasteland such as entisol. Similar results was also propounded by Sohrabi et al. ${ }^{13}$, depicts variations in $A G B$ and $C$ stocks in different tree plantations. The value of $A G B$ and $C$ stocks was comparatively lower in species planted in entisol soil except $A$. lebbeck, E. globulus and T. arjuna than others findings ${ }^{14,15}$, might be due to poor growth rate of the tree plantations in this site. The $\mathrm{C}$ storage potential depends on the growth performance and biomass accumulation of the species, therefore these attributes may be considered for choosing tree species for plantations in different sites.

\section{REFERENCES}

1. Dhruw, S.K., Singh, LJ. and Singh, A.K., Storage and Sequestration of carbon by leguminous and non leguminous trees on red lateritic soil of Chhattisgarh. Indian Forester, 135 (4): 531-538 (2008)

2. F.A.O., Global forest resources assessment 2010 - main report. FAO forest Paper No. 163, Rome (2010)

3. Keeling, C.D. and Khorf, T.P., Atmospheric $\mathrm{CO}_{2}$ records from site in the $\mathrm{SIO}$ air sampling network II trends: A compendium of Data on Global Change, Carbon Dioxide. Information analysis Center. Oak Ridge Laboratory, US Department of Energy, Oak Ridge Tenn, USA (2002)

4. Yin, W., Yin, M., Zhao, L. and Yand, L., Research on the measurement of carbon storage in plantation tree trunks based on the carbon storage dynamic analysis method. International Journal of Forestry Research, 2012: 1-10 (2012)

5. Liu, G.H., Fu, B.J. and Fang, J.Y., Carbon dynamics of Chines forests and its contribution to global carbon balance. Act Ecologica Sinica, 20 (5): 733-740 (2000)

6. Zanne, A.E., Lopez, G., Comes, G., Ilie, D.A., Jonson, S. and Lewis, S.L., Global wood density database (2009)

7. Hangarge, L.M., Kulkarni, D.K., Gaikwad, V.B., Mahajan, D.M. and Chaudhari, N., 2012. Carbon sequestration potential of tree species in Somjaich rai (Sacred grove) at Nadghur village, in Bhor region of Pune district, Maharastra State India. Annals of Biological Research, 3(7): 3426-3429 (2012)

8. Pearson, T.R.H., Brown, S. and Ravindranath, N.H., Integrating carbon benefits estimates into GEF project 1-56 (2005)

9. Kaul, M., Mohren, G.M.J. and Dadhwal, V.K., Carbon storage and sequestration potential of selected tree species in India. Mitigation Adoption Strategy Global Change, 15: 489510 (2010)

10. Pandya, I.Y., Salvi, H., Chahar, O. and Vaghela, N., Quantitative analysis on carbon storage of 25 valuable tree species of Gujarat, Incredible India. Indian Journal of Science Research, 4(1): 137-141 (2013)

11. Suryawanshi, M.N., Patel, A.R., Kale, T.S. and Patil, P.R., Carbon sequestration Potential of tree species in the environment of North Maharastra University campus, Jalgaon [MS] India. Bioscience Discovery, 5(2): 175-179 (2014)

12. Yuanqi, C., Zhanfeng, L., Xingquan, R., Xiaoling, W., Chenfei, L., Yongbiao, L., Lixia, Z., Xi-an, C. and Shenglei, Fu., Carbon Storage and Allocation Pattern in Plant Biomass among different forest plantation stands in Guangdong, China. Forests, 6: 794-808 (2015)

13. Sohrabi, H., Bakhtiari, S.B. and ahmadi, K., Above and below ground biomass and carbon stocks of different tree plantations in Central Iran. Journal of Arid Land, 8(1): 138-145 (2016)

14. Chaturvedi, R.K., Raghubanshi, A.S. and 
Singh, J.S., Carbon density and accumulation in woody species of tropical dry forest of India. Forest Ecology and Management, 262: 15761588 (2011)

15. Borah, N, Nath, A.J. and Das, A.K., Above ground biomass and carbon stocks of tre species in tropical forests of Cachar district, Assam, North east India. International Journal of Ecology and Environmental Sciences, 39(2): 97-106 (2013) 